\title{
Diversity of Coral Fish At Saebus Island, East Java, Indonesia
}

\author{
Siti Fatimah* ${ }^{* 1,2}$, Tri Widya Laksana Putra ${ }^{1,2}$, Putranto Kondang ${ }^{1,2}$, Suratman ${ }^{1,2}$, Larossa Gamelia $^{1,2}$, Hendry Syahputra ${ }^{1,2}$, \\ Rahmadayanti ${ }^{1,3}$, Mada Rizmaaadi ${ }^{1,2}$, Ambariyanto Ambariyanto ${ }^{2,4}$ \\ 1UKSA-387 Diving Club Diponegoro University, 50275 Jl. Prof. Soedarto SH, Tembalang Campus, Semarang, Indonesia \\ ${ }^{2}$ Faculty of Fisheries and Marine Science, Diponegoro University, 50275 Jl. Prof. Soedarto SH, Tembalang Campus, Semarang, \\ Indonesia \\ ${ }^{3}$ Faculty of Public Health, Diponegoro University, 50275 Jl. Prof. Soedarto SH, Tembalang Campus, Semarang, Indonesia \\ ${ }^{4}$ Coastal Disaster Rehabilitation and Mitigation Center, Integrated Laboratory, Diponegoro University, 50275 Jl. Prof. H. Soedarto, SH, \\ Tembalang, Semarang, Indonesia
}

\begin{abstract}
Coral reef ecosystem is known as an important place to live various types of fish, where coral conditions will affect the diversity and abundance of the fish. In healthy coral reef ecosystems generally can be found many types of fish with high density. This research aims to investigate the diversity and abundance of coral fishes at Saebus Island, East Java. The observation conducted at 4 stations, according to cardinal point by UVS (underwater visual census) methods with belt transect with the visibility of $2,5 \mathrm{~m}$ horizontally, and $5 \mathrm{~m}$ vertically. The length of transect was $100 \mathrm{~m}$ parallel with coastline, with the area of observation is $500 \mathrm{~m} 2$. The censuses were conducted at 2 different depths ( 3 and $10 \mathrm{~m}$ ). This study found 70 kinds of coral fish originated form 20 family at all stations. These fishes were from 3 different fish categories i.e. 7 target fishes, 13 indicator fishes, and 50 major fishes. Three different fishes that dominated target fish, indicator fish and major fish were Epinephelus fasciatus, Chaetodon baronessa and Aulostomus chinensis, respectively. There was similar value of fish diversity index at two different depths which were 3.635 and 3,623 . While uniformity index at the depth of $3 \mathrm{~m}$ was 0.153 and at $10 \mathrm{~m}$ was 0.217 , and domination index at the depth of $3 \mathrm{~m}$ was 0.11 and at $10 \mathrm{~m}$ was 0.167 . These values suggest that diversity of coral fish at Saebus island can be categorized as high diversity.
\end{abstract}

\section{Introduction}

Coral reef ecosystem has important and diverse benefits, ecologically and economically. The benefits are include as living area for fishes, as the object of marine tourism, and for research as well as utilization of aquatic organisms existing on coral reefs [1]. Disturbances of this ecosystem, such as destructive fishing, boat anchor, pollution, diseases, and climate change, will gives detrimental effects on the ecosystem $[2,3,4,5,6]$. In the condition of worst scenario it will bring about changes in biodiversity within the ecosystem and leading to extinction [7]

The existence of coral reef as a coastal area ecologically functioned as a habitat for many organisms, including reef fishes. The function of coral reef for these fishes can be as their shelter [8], spawning, nursery grounds [9] and food sources [10]. Therefore, the existence of reef fishes community become important indicator for health level coral reefs ecosystems [11].

Saebus Islands administratively located in Sumenep Regency. Geographically located between $6^{0} 50^{\prime}$ SL- $115^{0} 25^{\prime}$ WL. Kangean Islands consisted of several islands, among of them are
Sadulang Besar Island, Sadulang Kecil Island, Pagerungan Besar Island, Pagerungan Kecil Island, Sapeken Island, Sepanjang Island, Saubi Island, Paliat Island, Sepapan Island, Sasiil Island, Sepangkur Island, Sabuntan Island, Saebus Island, Saor Island, and Mamburit Island [12].

Saebus Island based on Bakorsurtanal (2009) survey result have the most large area of coral reef among other 7 district on East Java, with the area of $40.083,71 \mathrm{Ha}$ from the total of 49.257,98 $\mathrm{Ha}$. Saebus Island have a good coastal ecosystems as pictured by the growth of sea grass ecosystems, mangrove ecosystems and large area of coral reefs. The livelihoods of Saebus people are fishermen and farmers. Fishermen in Saebus Island take advantage of natural resources, especially fish as a source of income. Many fisherman catch fish by destructive fishing methods and destroying coral reef ecosystems [13].

Saebus has largest area of coral reefs, with high rate of fishing from local residents, but ecological study for reef fish information still hard to get. Ecological study for reef fishes such as reef fish community, including abundance, diversity, uniformity and dominancy of coral reef is needed to justify that coral reef ecosystem conditions is

\footnotetext{
Corresponding author: sitifatimahh@hotmail.com
} 
optimally functioned. This study investigates the diversity, uniformity and dominancy from reef fish abundance at Saebus island.

\section{Methods}

This research was conducted at Saebus Island, Sapeken, Sumenep, Madura, East Java (Figure 1). The fish surveys were done at four stations from 4 cardinal point of the Island.

\subsection{Data collection}

Coral reef condition was determined by using Line Intercept Transect (LIT) observation [14] at 4 different stations at the depth of $3 \mathrm{~m}$ and $10 \mathrm{~m}$ by UVS (Underwater Visual Sensus) method [15] Surveys were done by scuba diving for $100 \mathrm{~m}$ long with the radius of belt transect $2,5 \mathrm{~m}$ both to the left and right sides and $5 \mathrm{~m}$ upright. Therefore, total area of survey was $500 \mathrm{~m}^{2}$ for each station and each water depth.

Coral reef data were collected by measuring the diameter and record coral genus found along transect lines. Percentage of coral reefs community cover was obtained using Gomez and Yap formula [16]. All fish found were grouped as target, indicator and major fishes.

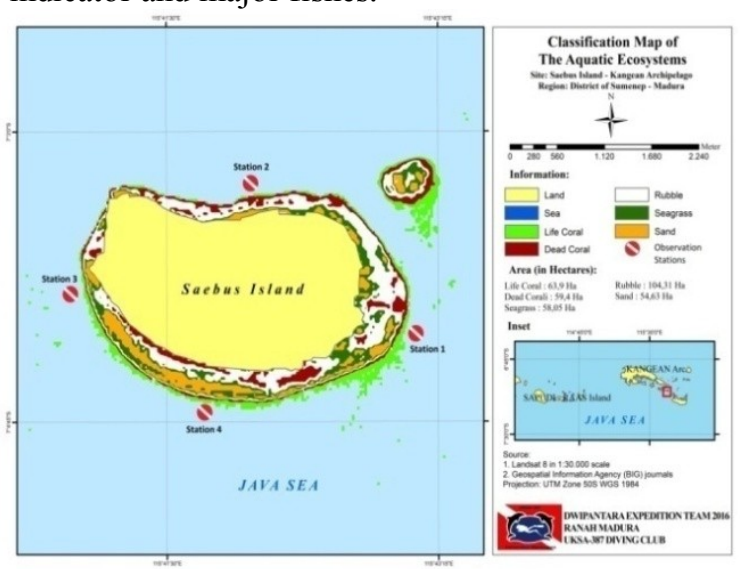

Fig. 1. Four stations for survey reef fishes at coral reef ecosystems around Saebus island waters

\subsection{Data analysis}

The number of fishes was estimated by equation [17]. Correlation value between coral coverage and fish abundance was calculated according to Pratisto [18]. Description of a population can be determined by the number of individuals of each species in the community [19]. The structure of the population can be seen by value of diversity index, which is categorized based on EPA [20]. Community balance measurement was calculated by uniformity index (E) ranging from 0 to 1 [21]. Dominancy index represent dominancy rate of one area and the value ranging from 0 to 1 [19].

\section{Results}

\subsection{Fish abundance}

Total number of reef fish found was 1633 individuals within total area of $4000 \mathrm{~m}^{2}$ at all 4 stations at depth of 3 and $10 \mathrm{~m}$, dominated by major fish (1500 indv.) compared with indicator fish (73 indv.) and target fish (60 indv.) see Table 1. There were 7 species of target fish from 3 families i.e. Serranidae, Haemulidae and Lutjanidae. Eleven species of indicator fish that categorized as Chaetodontidae. While for major fish, there were 50 species of fish from 15 families.

There are differences on the number of fish found in each station. More than half of target fish were found at station 4, and only one fish at station 1. Similarly, no indicator fish was found at station 3 , while at other station the number was quite similar. On the other hand, major fishes were dominated at all stations and the number was much higher compared with other fishes

Table 1.Total of individual of target fish, indicator and major at each research stations on Saebus Island

\begin{tabular}{|c|c|c|c|}
\hline Station & Target & Indicator & Major \\
\hline 1 & 1 & 26 & 352 \\
\hline 2 & 15 & 26 & 438 \\
\hline 3 & 10 & 0 & 232 \\
\hline 4 & 34 & 21 & 478 \\
\hline Total & $\mathbf{6 0}$ & $\mathbf{7 3}$ & $\mathbf{1 5 0 0}$ \\
\hline
\end{tabular}

\subsection{Correlations of fish abundance and coral coverage}

There was different correlation of reef fish abundance and coral coverage percentage at two water depth. See Table 2.

Table 2. Abundance Value $(\mathrm{N})$ of Coral Fish and Coral Coverage

\begin{tabular}{|c|c|c|c|}
\hline Station & Depth (m) & $\mathbf{N}$ & Coral Cover (\%) \\
\hline 1 & 3 & 0.510 & 57.38 \\
\hline & 10 & 0.448 & 78.08 \\
\hline 2 & 3 & 0.404 & 62.59 \\
\hline & 10 & 0.354 & 61.81 \\
\hline 3 & 3 & 0.196 & 74.56 \\
\hline & 10 & 0.288 & 44.80 \\
\hline 4 & 3 & 0.434 & 62.89 \\
\hline \multicolumn{2}{|l}{} \\
\hline
\end{tabular}

Based on the correlation analysis between fish abundance value and coral reef coverage percentage on the depth of $3 \mathrm{~m}$ have negative relationship. This result shown by the negative 
regression value which is $-0,9875$ (Figure 2 ). The least fish abundance value is on station 3 on the depth of $3 \mathrm{~m}$. At this station and at the same depth shown high coral reef coverage which is $74.56 \%$.

Correlation value between fish abundance and coral reef coverage percentage on the depth of 10 $\mathrm{m}$ at each station have value of $\mathrm{R}=0.0164$ (Figure 3 ). This correlation value is very low, which mean the correlation rate of 2 variables only shown on the 0.0164 interval. While the positive value indicates that the higher fish abundance the higher percentage of coral coverage [22].

This result is not in accordance with other studies which generally found that the higher the percent cover of corals, the higher the abundance of the fish [23]. There are two possibilities in explaining this result. First, the number of samples probably too small (only four points). Secondly, abundance of fish is influenced by many aspects including the complexity of the habitat [24].

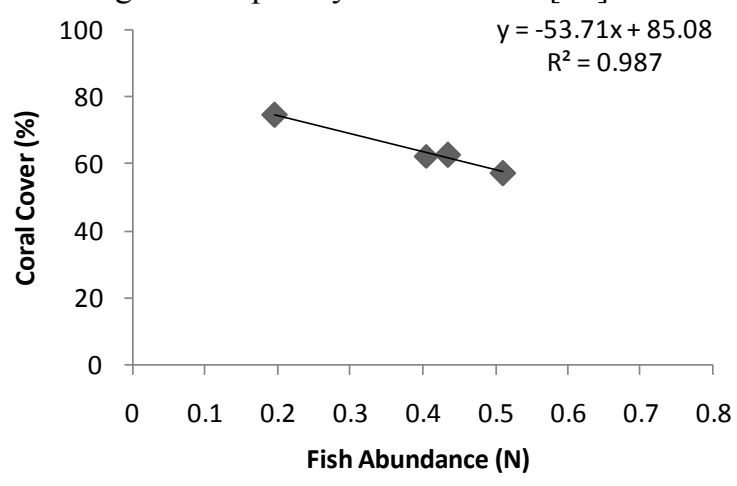

Fig. 2. Correlation of coral reef fish abundance and coral coverage at 3 meters depth

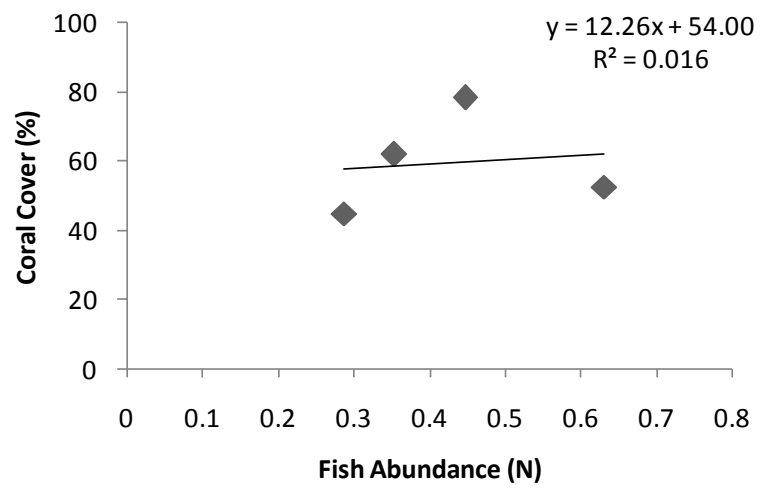

Fig. 3. Correlation of coral reef fish abundance with coral coverage at 10 meters depth

\subsection{Ecological index of reef fish}

The value of coral reef fish diversity indices $\left(\mathrm{H}^{\prime}\right)$ from four stations, although they are not similar but all lay in medium category.
Table 3.Saebus Island's Ecological Indices

\begin{tabular}{|c|c|c|c|}
\hline Station & $\mathbf{H}^{\prime}$ & E & D \\
\hline 1 & 3.054 & 0.273 & 0.224 \\
\hline 2 & 2.727 & 0.166 & 0.112 \\
\hline 3 & 2.782 & 0.174 & 0.118 \\
\hline 4 & 3.202 & 0.126 & 0.101 \\
\hline
\end{tabular}

The values of uniformity indices were quite similar and they are in low category since the values are all below 0.4. While based on the result of the dominant indices where no value is close to 1 , which means that no individual dominates in the population. See Table 3.

\section{Discussion}

\subsection{Reef fish abundance}

The smallest number of individuals of target fish was found at station 1. It is suspected that the coral reef fishing activities in Saebus Island is relatively intensive especially in station 1 . The abundance of target fishes, a group of small fish predator such as Serranidae, Lutjanidae, Lethrinidae and Carangidae, became low due to intensive fishing activities [25]. Structural changes of target fish communities show variations in environmental factors because the target fish have properties that are integrated with the coral reef condition [26, 27,28].

The very low appearance of indicator fish, in station 3, can be caused by the hydro-oceanography factor of the waters causing the instability of the water balance. The indicator fish found was from Chaetodontidae family which is known as important and widely studied fish family in coral reef[29].Fish belonging to the Chaetodontidae family group have strong associations with coral and can be used as an indicator of coral health [30, 31]. Total number of Chaetodontidae species have significant correlation to hard coral coverage [32]. However, not at all Chaetodontidae fish is hard coral eaters (scleractinian coral), there are also octocoral (soft corals eaters) such as Chaetodon melannotus [33]. This observation found $19 \mathrm{indv}$. which is dominated by the genus Chaetodon.

A total of 50 major fish species were found during the observation comes from 15 families. The families considered to be significant in the group are the Pomacentridae, Labridae and Pomachantidae groups. Most of fish have relatively small body size and in nature play an important role in the food chain, especially as food supply for carnivorous fish. The study also found some of types of fish have beautiful body colour so potentially exploited by ornamental fish enthusiasts or for diving attractions. 


\subsection{Fish abundance value and coral coverage correlation}

The correlation between the complexity of coral reef types and the diversity of fish communities indicates that the structure of the reef fish community can be affected by the physical complexity of the substrate [34]. Based on correlation analysis of reef fish abundance value with coral cover percentage at depth of 3 meter in all station have correlation relationship. The phenomenon of low coral reef abundance in station 3 of $3 \mathrm{~m}$ depth can be caused by hydrooceanographic condition of waters causing the instability of water balance [22]. On the other hand, this depth is an area that can be accessed directly by fishermen, but the behaviour of local communities in fishing is still not good, such as using potassium. The factors of behaviour to fulfil economic needs are exploitation without considering sustainability of the fish, resulting in abundance of fish that is inversely proportional to coral cover. The activities of local communities gave negative impact to the balance of coral reef ecosystems including fish in it [35]. The less complex habitat in coral waters will provide smaller ecological niches for associated marine organisms [36]. At this location the ecological niche areas are relatively small so that fish abundance has a negative correlation on coral cover. Abundance of fish is influenced by many aspects including the complexity of the habitat [24].

A positive correlation between the abundance of reef fish and the percentage of coral coverage is shown in the depths of $10 \mathrm{~m}$. There is a positive linear relationship between the percentage of live coral coverage and the number of reef fish species $[37,38]$. Reef fish have narrow ecological niches so more species can inhabit (accommodate) coral reefs. Consequently, certain types of reef fish are limited and localized only in certain areas of coral reefs [39]. Luckhurst and Luckhurst [38] examined relationship between reef fish community parameters and substrate diversity, and abundance of coral species indicated that significant relations were found.

\subsection{Diversity, uniformity and dominancy indices}

The diversity of reef fish in the Saebus Island are medium diversity category. These results suggest that the surrounding environmental conditions are in stable condition, both the water quality and the coral reef ecosystem. Diversity and abundance of reef fish is increasing with increasing complexity of coral habitat [41]. Reef fish have various roles, ie, as plant-eaters, predators, and also play a role in calcium erosion to produce sediment [42].
However, diversity will significantly decline if the ecosystems have to face destructive events and activities [7].

The result of uniformity index is $E<0,4$ which mean low level of uniformity. This illustrates that ecosystem equilibrium occurs in the environment because of the high diversity of fish, there is no high level of fish dominance or abundance of one species of reef fish.

\section{Conclusion}

It has been found the number of individual reef fish 1633 individual which comes from 7 species of target fish of 3 families. Butterfly fish from Chaetodontidae found 13 species and major fish as many as 50 species from 15 families. The largest abundance of reef fish was the major fish group.

The correlation between abundance of reef fish and the percentage of coral coverage shows a negative correlation at $3 \mathrm{~m}$ and positive correlation at $10 \mathrm{~m}$ depth. This is probably caused by hydrooceanographic conditions causing instability of aquatic conditions. The diversity of reef fish can be categorized as medium with the value of 2,272 3,202 . The Uniformity Index (E) value of $0.273-$ 0.126 categorized as low category. The value of the dominance index (D) 0.224-0.112 indicates there is no dominance between fish species in Saebus Island.

\section{Acknowledgements}

This research was held by UKSA-387 Diving Club Diponegoro University on Dwipantara V Expedition: Kangean Archipelago "Jelajah Pesona Bahari Tampuk Timur Madura". We thanks to UKSA-387 families who fully supported and big appreciation to the the Team who has worked hard in this project. This project depends on logistical and field support from a number of contributed peoples. We thanks to the Department of Fisheries and Marine East Java Province, Indonesia. Mr. H. Muhammad Ali, Mr. Osnan, Saur-Saebus village and Sapeken Sub-district governments, as well as the entire community of Saebus and Sapeken Islands for supporting this research.

\section{References}

1. Sukandarrumidi. Yayasan Pustaka Nusantara, Yogyakarta. (2009)

2. E.N. Edinger, J. Jompa, G.V. Limmon, $W$. Widjatmoko, and Risk, M.J. Marine Pollution Bulletin, 36, 8: 617-630 (1998)

3. J.A. Maynard, K. R. N. Anthony, S. Afatta, L. F. Anggraini and D. Haryanti, Ambariyanto, 
A. Pacific Conservation Biology, 14, 4: 242243 (2009).

4. Hoegh-Guldberg, O., Hoegh-Guldberg, H., Veron, J.E.N., Green, A., Gomez, E.D., Lough, J., King, M., Ambariyanto, A., Hansen, L., Cinner, J., Dews, G., Russ, G.,Schuttenberg, H.Z., Peñaflor, E.L., Eakin, C.M., Christensen, T.R.L., Abbey, M., Areki, F., Kosaka, R.A., Tewfik, A., Oliver, J. WWF Australia. (2009)

5. Ambariyanto. Ilmu Kelautan, 16, 1: 30-34 (2011)

6. A. Sabdono, O. K. Radjasa, A. Ambariyanto, A. Trianto, D.P. Wijayanti, D. Pringgenies, Munasik. International Journal of Zoological Research, 10, 2: 1-10 (2014)

7. Ambariyanto. IOP Conference Series: Earth and Environmental Science. 55, 1: 012002 (2017)

8. A. Yanuar, and Aunurohim. J. Science and Art, 4,1: E19-E24 (2015).

9. F. Setiawan, T.B. Razak, E. Idris, J. Trop. Mar. Sci. Technol.5,2: 377-390 (2013)

10. I Manembu, L. Adrianto, D.G. Bangen, and F. Yulianda. J. Fisheries Mar. Trop, 8,1:28-32 (2012)

11. T.F. Hourigan, C.T. Timothy, and E.S. Reese, Marine organisms as indicators. pp: 107-135. Springer New York. (1988)

12. Djojoprajitno, S. Bul. Kangean Nyiur Melambai. (2005)

13. B. Tamam, J. Kel. 6,2:1907-9931 (2013)

14. S. English, C. Wilkinson, and V. Baker, Australian Institute of Marine Science, Townsville,368 pp. (1994).

15. I. Hill, and C. Wilkinson. Australian Institute of Marine Science, Townsville, $117 \mathrm{pp}$ (2004)

16. E. D. Gomez, and H. T. Yap, UNESCO Regional Office for Science and Technology for South East Asia, Jakarta, (1988)

17. Suharsono. Oceanology Research and Development Center - LIPI, Jakarta, (1995)

18. A. Pratisto, Elex Media Komputindo,Jakarta, 282 pp. (2005)

19. Odum, E.P. W. B. Sounders Company Ltd, Philadelphia, (1971)

20. EPA. US Environmental Protection Agency, Wangsinton, 595 pp.(1973)

21. J.E. Brower, and Zar, J.H.WM Brown Comp. Pub., Dubuque-Lowa, 194 pp. (1977)

22. Mujiyanto, B.I. Purnawati, Hartati, S.T. Proc. Nat. Forum of Fish Res.II:KR-13 (2009)
23. J.D. Bell, and R. Galzin, Influence of live coral cover on coral-reef fish communities. Marine Ecology Progress Series, pp.265-274, (1984)

24. C.M. Roberts, and R.F. Ormond, 1987. Habitat complexity and coral reef fish diversity and abundance on Red Sea fringing reefs. Marine Ecology Progress Series, pp.18.Russ, G.R.and A.C. Alcala. Mar. Ecol. Prog. Ser, 10: 13-27. (1989)

25. J.H. Choat, D.R. Bellwood, Department of Zoology University of New Hamshire Durham. p. 39-47 (1991).

26. A.J. Dartnall, M. Jones, Australian Institute of Marine Science,Townsville, 166 pp. (1986)

27. R.H. Kuiter, Gramedia Pustaka Utama, Jakarta, (1992)

28. D. McB. Williams, and A.I. Hatcher. Mar. Ecol. Prog. Ser,10: 239-250 (1983)

29. Reese, E.S. Bull. Mar. Sci, 31: 594-604. (1981).

30. T.F. Hourigan, T.C. Tricas, E.S. Reese, New York: Springer - Verlag $107-135$ p (1988)

31. White, A.T. Proc. $6^{\text {th }}$ Int. Coral Reef Symp.2 (1988)

32. P.M. Alino, P.W. Sammarco, J.C. Coll, $6^{\text {th }}$ Int. Coral Reef Symp. 3:31-36. (1988)

33. J.D. Bell, and R. Galzin, Mar. Ecol. Prog. Ser., 15: 265-274 (1984)

34. M. Adrim, S.A. Harahap, K. Wibowo, Ilmu Kelautan, doi: https://doi.org/10.14710 /ik.ijms.17.3.154-163 (2012).

35. Hartoni, A. Damar, and Y. Wardiatno, MASPARI Journal Institut Pertanian Bogor, 4,1: 46-57 (2012).

36. Mujiyanto. Prosiding Seminar Nasional Perikanan Indonesia: 317-325 (2012).

37. H. Malikusworo, Training Course in Coral Reef Research Methods and Management. March 25 - April 30. Bogor. Indonesia. Seameo-Biotrop. (1986).

38. Ilham. Thesis. Faculty of Marine Science and Fisheries, UNHAS Makassar, (2007).

39. B. E. Luckhurst, and L. Luckhurst. Mar. Biol. 49: 317-323. (1978).

40. Risk, M. J. Atoll Research Bulletin 153. Washington UNEP. (1993).

41. Lowe-McConnell, R. H.Cambridge University Press, Cambridge, (1987).

42. T. A. Yadi, A. Pratomo, F. Yandri, J. Mar. Sci. Prog. (2013) 